\title{
Glycogen persistence in ultramarathon athletes after six hours of exercise
}

\author{
Tarini $\mathrm{VAF}^{1,2}$, Kelencz $\mathrm{CA}^{3 *}$, Zanuto $\mathrm{R}^{1}$ and Lotufo $\mathrm{R}^{2}$ \\ ${ }^{1}$ Physical Education Department of Centro Universitário Adventista de São Paulo, Brazil \\ ${ }^{2}$ Neuromuscular Diseases Investigation Sector of Universidade Federal de São Paulo, Escola Paulista de Medicina, São Paulo Brazil \\ ${ }^{3}$ Centro College Uniradial Estácio, Sao Paulo, Interlagos, Brazil
}

\begin{abstract}
Glycogen, a branched glucose polymer, is the main store of readily available energy in mammalian skeletal muscle and plays a key role in muscle function as demonstrated by the inability to sustain prolonged high-intensity exercise when glycogen stores are depleted.

Context: To determine the effect of ultra-endurance exercise on the intramuscular glycogen reserves of an ultra-marathon runner.

Case report: An athlete ran for six consecutive hours with no caloric replacement. Biopsies of the Vastus lateralis were taken pre and post exercise. The fragments were frozen and later histochemically prepared using the PAS technique. Significant amounts of glycogen were found in the post-exercise sample. Conclusion: Ultra endurance exercise cannot fully deplete glycogen in muscle of trained individuals.
\end{abstract}

\section{Introdution}

Glycogen, a branched glucose polymer, is the main store of readily available energy in mammalian skeletal muscle and plays a key role in muscle function as demonstrated by the inability to sustain prolonged high-intensity exercise when glycogen stores are depleted.

A 36-year.-old, $162 \mathrm{~cm}$ tall, $60.9 \mathrm{Kg}$ body mass weight, $24 \mathrm{hr}$ race champion runner signed consent term and UNIFESP Ethics Committee on Human Research approved all procedures (protocol number: 2061/07).

\section{Methodology}

The athlete was submitted to a muscular biopsy taken from the distal vastus lateralis muscle region. The methodology employed was that proposed by Dubowitz [1,2]. A small fragment was taken after a $48 \mathrm{hr}$ of rest period and the PAS muscular glycogen identification histochemical technique applied. The muscle fragment extracted was immediately fixed and frozen in isopentane, refrigerated in liquid nitrogen and properly stored at $-80^{\circ} \mathrm{C}$ for future analysis (Figure 1a).

A thirty-day recovery period was proposed, after which time the athlete could perform the six-hour running session. The running procedure was performed on a RT 250 pro São Paulo Brazil Movement ${ }^{\oplus}$ treadmill at a $1 \%$ gradient. The suggested running speed was ten kilometers per hour $(10 \mathrm{~km} / \mathrm{h})$, the same speed comfortably maintained by the athlete in competitions. An S120 Polar Finland heart rate monitor was used to monitor effort intensity. The athlete was advised to eat properly as well as to be adequately hydrated during the days leading up to the exercise session.

On the test day the athlete attended the exercise session venue 3 hours after a standard breakfast, which was composed by $100 \mathrm{gr}$ of bread with $20 \mathrm{gr}$ of butter, a cup containing $250 \mathrm{ml}$ of milk with coffee, which was similar in content and composition to that which he would normally ingest before competition. Our athlete's heart rate at rest was recorded along with weight on 2096 PP Toledo ${ }^{\circledR}$ São Paulo-Brazil scales which weighed up to $200 \mathrm{~kg}$ in 50 gram graduations (Table 1). The athlete was wearing only running clothes, which included a pair of running shoes.

Following a proper warm up the running session was begun. Throughout the exercise period only water was offered to the athlete, such that no energetic supplement was used. Every full hour the runner came down from the treadmill to urinate. Subsequently body mass and heart rate were recorded to monitor for dehydration. This protocol was used because it mimics our athlete race, and the purpose of the study was to determine if a typical race could completely deplete glycogen stores.

After six hours the athlete was immediately submitted to a vastus lateralis muscle biopsy on the opposite limb had been used in the first biopsy. The fragment was immediately frozen and later prepared and histochemically stained to detect the presence of glycogen (Figure 1b).

\section{Results}

The analysis of the biopsies pre and post ultra-endurance exercise, shown in Figure 1a and $1 \mathrm{~b}$ respectively, reveal a discreet reduction of intramuscular glycogen in Figure 1b, evidenced by slight color reduction in some muscle cells.

Correspondence to: Carlos Alberto Kelencz, Centro College Uniradial Estácio, Sao Paulo, Interlagos, Brazil, E-mail: carlos.ak@ig.com.br

Key words: physical endurance, PAS, glycogen

Received: April 21, 2016; Accepted: May 12, 2016; Published: May 16, 2016 


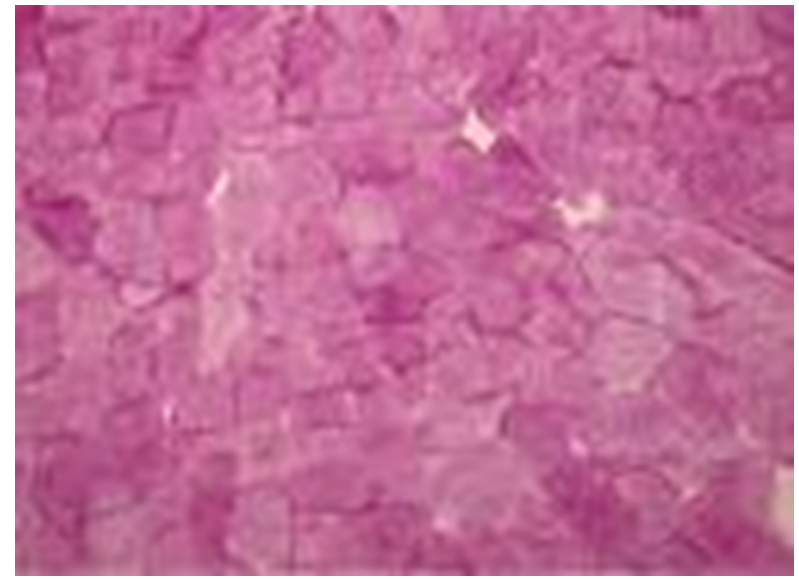

Figure 1a. Pre exercise biopsy of vastus lateraliscolor edhisto chemically with PAS. x 125. Normal PAS

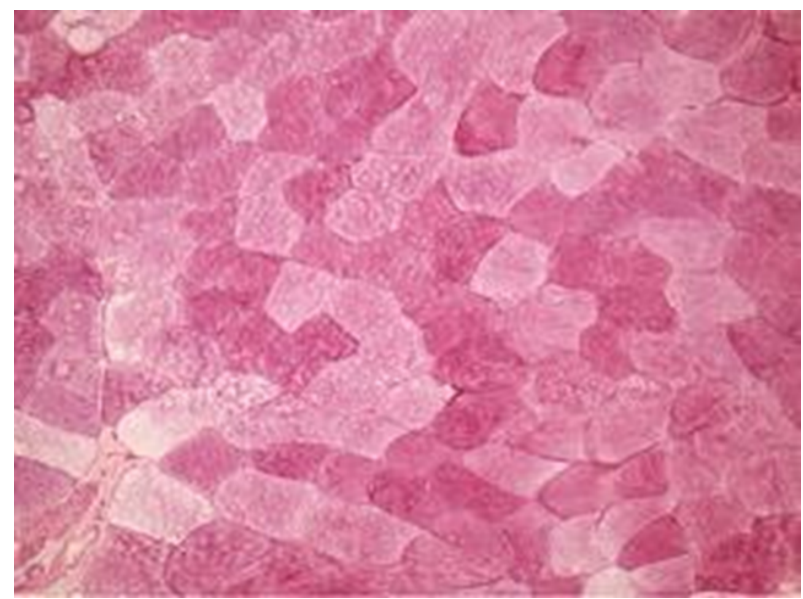

Figure 1b. Post exercise biopsy of vastus lateraliscolore dhisto chemically with PAS. There was a difference of color intensity in post exercise. However, large amounts of glycogen still remain in depleted cels at the present slice. x 125.

Table 1. Assumptions of intramuscular glycogen.

\begin{tabular}{|c|c|c|c|}
\hline Time (hr) & HR. (Bpm) & TBM. $(\mathbf{K g})$ & VEL. $(\mathbf{k m} / \mathbf{h})$ \\
\hline REP. & 50 & 60.5 & 0.0 \\
\hline $1^{\text {st }}$ & 125 & 59.5 & 10.0 \\
\hline $2^{\text {nd }}$ & 125 & 59.3 & 10.0 \\
\hline $3^{\text {rd }}$ & 138 & 59.0 & 10.0 \\
\hline $4^{\text {th }}$ & 147 & 59.1 & 10.0 \\
\hline $5^{\text {th }}$ & 152 & 59.3 & 10.0 \\
\hline $6^{\text {th }}$ & 150 & 59.3 & 10.0 \\
\hline Mean $\left(1^{\text {st }}\right.$ to $6^{\text {th }}$ hr $)$ & 139.5 & 59.3 & 10.0 \\
\hline
\end{tabular}

\section{Discussion}

The present study investigated the effect of ultra-endurance exercise on intramuscular glycogen reserves. Our results show that ultra-endurance exercise to exhaustion promoted muscle glycogen depletion predominantly in a specific type of muscle fibres. Although there are studies in the scientific literature that have observed muscle metabolism behaviour in ultra-prolonged exercise [3-5], ultra exercise effects with no caloric supplementation to intramuscular glycogen reserves have not yet been reported. In our research we decided to evaluate muscular metabolism performance under conditions never previously investigated. The athlete underwent a six-hour running session on a treadmill in a post absorptive state while receiving no caloric supplementation. Despite these conditions large amounts of muscular glycogen were observed in depleted muscle cells Figure 1b. The assumptions that may explain this intramuscular glycogen presence are as follows:

Firstly, after the beginning of the exercise and upon gradual decrease in intramuscular glycogen, a heterotrimeric serine/treonine protein kinase, recently described as 5'AMP- activated protein kinase (AMPK), acts as an important intracellular AMP/ATP and creatine/ phosphocreatine rate sensor [6]. There is evidence that it is regulates according to the variation in muscular glycogen reserves. AMPK is found in its active form during exercise and increases with effort intensity $[7-11,12]$. Its function is probably to translocate the GLUT4 carrier protein to the cell membrane, where GLUT4 is the most important glucose carrier isoform during exercise. This capture is particularly important since blood flow to active muscles can increase up to twenty fold during intense exercise. Initially, this process probably prevents a critical reduction of intramuscular glycogen reserves, since it increases in the same way as glyconeogenic activity in the liver $[4,13]$ However, during ultra-prolonged exercise glycemic levels would be significantly reduced if it were not for the glucose/fatty-acids cycle modulation known as the "Randle Cycle", which increases fatty-acid oxidation due to AMPK interaction with the Acetil CoA Carboxilase beta (ACC $\beta)$, which increases the fatty-acids supply at the cellular level [7]. The blood glucose supply constitutes a 2nd hypothesis. Defined as blood flow product divided by glycemic concentration, this is related to the amount of glucose carried by the blood which can reach the muscle arteries in the active muscles while facilitating its capture [14].

The $3^{\text {rd }}$ assumption is that some intramuscular glycogen "granules", also called glycosomes, perform a different role. These granules play a structural protein role participating in myofilament sliding and persist even after their death [15]. This fact alone would prevent PAS from showing a negative result for the intramuscular glycogen presence.

\section{Conclusion}

We conclude that six-hour ultra-prolonged exercise does not exhaust intramuscular glycogen on PAS even in the absence of caloric replacement during exercise. The most likely reasons for this persistence are: AMPK influence on GLUT4; initial plasmatic glucose levels; modulation of acetyl-CoA Randle Cycle entry and glycosomes presence which plays a structural role in myofilament adherence.

\section{References}

1. Dubowitz V, Brooke MH (1973) Muscle biopsy: a modern approach. WB Saunders, London, UK.

2. Dubowitz V (1986) Muscle biopsy: a practical approach. (2ndEdtn). BaillièreTindall, London, UK.

3. Helge JW, Rehrer NJ, Pilegaard H, Manning P, Lucas SJ, et al. (2007) Increased fat oxidation and regulation of metabolic genes with ultraendurance exercise. Acta Physiol (Oxf) 191: 77-86. [Crossref]

4. Jeukendrup AE, Moseley L, Mainwaring GI, Samuels S, Perry S, et al. (2006) Exogenous carbohydrate oxidation during ultraendurance exercise. J Appl Physiol 100: 1134-1141. [Crossref]

5. Alghannam AF, Jedrzejewski D, Bilzon J, Thompson D, Tsintzas K, et al. (2016) Influence of Post-Exercise Carbohydrate-Protein Ingestion on Muscle Glycogen Metabolism in Recovery and Subsequent Running Exercise. Int J Sport Nutr Exerc Metab. [Crossref]

6. Hardie DG, Carling D, Carlson M (1998) The AMP-activated/SNF1 protein kinase 
subfamily: metabolic sensors of the eukaryotic cell? Annu Rev Biochem 67: 821-855. [Crossref]

7. Chen ZP, McConell GK, Michell BJ, Snow RJ, Canny BJ, et al. (2000) AMPK signaling in contracting human skeletal muscle: acetyl-CoA carboxylase and NO synthase phosphorylation. Am J Physiol Endocrinol Metab 279: E1202-1206. [Crossref]

8. Derave W, Ai H, Ihlemann J, Witters LA, Kristiansen S, et al. (2000) Dissociation of AMP-activated protein kinase activation and glucose transport in contracting slowtwitch muscle. Diabetes 49: 1281-1287. [Crossref]

9. Fujii N, Hayashi T, Hirshman MF, Smith JT, Habinowski SA, et al. (2000) Exercise induces isoform-specific increase in 5'AMP-activated protein kinase activity in human skeletal muscle. Biochem Biophys Res Commun 273: 1150-1155. [Crossref]

10. Jørgensen SB, Viollet B, Andreelli F, Frøsig C, Birk JB, et al. (2004) Knockout of the alfa-2 but not alfa-1 5'-AMP-activated protein kinase isoform abolishes 5-aminoimidazole-4-carboxamide-1-beta-4-ribofurasonide but not contraction-induced glucose uptake in skeletal muscle. J Biol Chem 279: 1070-1079. [Crossref]
11. Frayn KN (2003) "The Glucose/Fatty Acid Cycle 1963-2003: A Tribute to Sir Philip Randle". The glucose-fatty acid cycle: physiological perspective. Biochemical Society Transactions 31: 1115-1119.

12. Tyler CJ, Reeve T, Hodges GJ, Cheung SS (2016) The Effects of Heat Adaptation on Physiology, Perception and Exercise Performance in the Heat: A Meta-Analysis. Sports Med. [Crossref]

13. Adeva-Andany MM, González-Lucán M, Donapetry-García C, Fernández-Fernández C, Ameneiros-Rodríguez E (2016) Glycogen metabolism in humans. Biochimicaet biophysicaacta clinical 5: 85-100. [Crossref]

14. Shearer J, Graham TE (2004) Novel aspects of skeletal muscle glycogen and its regulation during rest and exercise. Exerc Sport Sci Rev 32: 120-126. [Crossref]

15. Rose AJ, Richter EA (2005) Skeletal muscle glucose uptake during exercise: how is it regulated? Physiology (Bethesda) 20: 260-270. [Crossref]

Copyright: $\mathbb{C} 2016$ Tarini VAF. This is an open-access article distributed under the terms of the Creative Commons Attribution License, which permits unrestricted use, distribution, and reproduction in any medium, provided the original author and source are credited. 